\title{
Determination of selected pesticides in water samples adjacent to agricultural fields and removal of organophosphorus insecticide chlorpyrifos using soil bacterial isolates
}

\author{
M. S. Hossain • M. Alamgir Zaman Chowdhury • \\ Md. Kamruzzaman Pramanik • M. A. Rahman • \\ A. N. M. Fakhruddin • M. Khorshed Alam
}

Received: 12 February 2013/Accepted: 10 March 2014/Published online: 23 March 2014

(c) The Author(s) 2014. This article is published with open access at Springerlink.com

\begin{abstract}
The use of pesticide for crops leads to serious environmental pollution, therefore, it is essential to monitor and develop approaches to remove pesticide from contaminated environment. In this study, water samples were collected to monitor pesticide residues, and degradation of chlorpyrifos was also performed using soil bacteria. Identification of pesticide residues and determination of their levels were performed by high-performance liquid chromatography with photodiode array detector. Among 12 samples, 10 samples were found contaminated with pesticides. Chlorpyrifos was detected in four tested samples and concentrations ranged from 3.27 to $9.31 \mu \mathrm{g} / \mathrm{l}$ whereas fenitrothion ranging from (Below Detection Limit, $<0.1 \mu \mathrm{g} /$ 1) to $33.41 \mu \mathrm{g} / \mathrm{l}$ in the tested samples. Parathion was found in two tested samples at the concentration of 0.73 and $6.23 \mu \mathrm{g} / \mathrm{l}$. None of the tested samples was found contaminated with Methoxychlor, DDT and Ethion. Three soil bacterial isolates, Pseudomonas peli BG1, Burkholderia caryophylli BG4 and Brevundimonas diminuta PD6 degraded chlorpyrifos completely in 8, 10 and 10 days, respectively, when $20 \mathrm{mg} / \mathrm{l}$ chlorpyrifos was supplied as sole source of carbon. Whereas, BG1, BG4 and PD6 took
\end{abstract}

M. S. Hossain · A. N. M. Fakhruddin ( $\square)$

Department of Environmental Sciences, Jahangirnagar

University, Dhaka 1342, Bangladesh

e-mail: a.fakhruddin2@mail.dcu.ie

M. A. Z. Chowdhury · M. A. Rahman · M. K. Alam Agrochemical and Environmental Research Division, Institute of Food and Radiation Biology, Atomic Energy Research Establishment, Savar, Dhaka 1349, Bangladesh

Md. K. Pramanik

Microbiology and Industrial Irradiation Division, Institute of Food and Radiation Biology, Atomic Energy Research Establishment, Savar, Dhaka 1349, Bangladesh
14, 16 and 16 days, respectively, for complete removal of $50 \mathrm{mg} / \mathrm{l}$ chlorpyrifos. Chlorpyrifos degradation rates were found maximum by all three isolates at 2 nd day of incubation for both tested concentrations. The results of the present study suggest the need for regular monitoring of pesticide residues in water, to protect the aquatic environment. Chlorpyrifos degrading bacterial isolates can be used to clean up environmental samples contaminated with the organophosphate pesticides.

Keywords Pesticides - Agricultural water · HPLC . Organophosphorus insecticide · Chlorpyrifos ·

Biodegradation · Bangladesh

\section{Introduction}

Agriculture is the main economic backbone of Bangladesh, which contributes about one-third to the country's gross domestic product (GDP) and $80 \%$ of the people depend on agriculture for their livelihood (Chowdhury et al. 2011; Bhattacharjee et al. 2012). However, agricultural production has increased in recent years with the introduction of highyielding cultivars of rice. But these high-yielding cultivars of rice are highly vulnerable to pests and diseases and dramatically reduce agricultural output. Therefore, like many other developing countries, pesticides are used extensively in Bangladesh to increase the crop yield (Shahjahan 1993; Dasgupta et al. 2007; Chowdhury et al. 2012b). Due to the widespread use of pesticides, their residues are detected in various environmental matrices, like soil, water and air. Pesticide contaminations of surface waters have been well documented worldwide and cause a major issue that gives rise to concerns at local, regional, national and global scales due to the adverse effects of pesticide on the environment (Planas 
et al. 1997; USGS 1999; Huber et al. 2000; Cerejeira et al. 2003). Pesticide residues reach the water body through direct runoff, leaching, careless disposal of empty containers, equipment washing etc. The amount of pesticides lost from agricultural fields and transported to surface waters depends on several factors, including soil characteristics, topography, weather, agricultural practices, and chemical and environmental properties of individual pesticides (Wagenet 1987; Leonard 1990). Chemical reactions and physical displacements influence the persistence of the chemicals in the soil and water, but with different environmental implications. Pesticides, which are sufficiently resistant to degradation and are adequately soluble to be transported in water, may reach the water bodies in significant amounts (Wagenet 1987).

For the treatment of water polluted with pesticides, many technologies have been evaluated including physicochemical and biological treatments. Biological treatment like biodegradation of pesticide using microorganisms has received increasing attention as an efficient, inexpensive and environmentally friendly approach to clean up pesticide-polluted environments (Xu et al. 2008). Chlorpyrifos [O,O-diethyl O-(3,5,6-trichloro-2-pyridyl) phosphorothioate] is used worldwide as an agricultural insecticide (Cho et al. 2002). There are numerous studies of chlorpyrifos insecticide degradation by microorganisms (Singh et al. 2004; Lakshmi et al. 2008; Anwar et al. 2009; Briceño et al. 2012). The aim of this paper is to determine the concentration of the selected pesticide residues in agricultural water samples of Savar Upazila and to degrade chlorpyrifos using soil bacteria.

\section{Materials and methods}

\section{Standard pesticides and chemicals}

Reference grade standards for methoxychlor (99.5\%), DDT $(99.0 \%)$, chlorpyrifos $(99.5 \%)$, diazinon $(99.5 \%)$, ethion $(99.0 \%)$, fenthion $(98.5 \%)$, fenitrothion $(99.0 \%)$, malathion (99.5\%), parathion (99.0\%), carbaryl (99.0\%), carbofuran $(99.5 \%)$ and cypermethrin (99.0\%) were purchased from GmbH (D-86199 Augsburg, Germany). The organic solvents including $n$-hexane (Merck, Germany), diethylether (BDH, England) and dichloromethane (Merck, Germany) were of analytical grade while acetonitrile (Scharlau, EU) was of HPLC grade. Anhydrous Sodium Sulfate (Merck, Germany), Florisil (Sigma, USA) and formulated chlorpyrifos (Master Plus) were also used.

Collection and preservation of water samples

Water samples from lakes adjacent to agricultural fields of Savar, Bangladesh were collected from February to March, 2012. The samples were kept in clean amber glass bottles, put into ice boxes and immediately transferred to the laboratory at the Institute of Food and Radiation Biology, Atomic Energy Research Establishment, Savar, Dhaka. Sample collection was performed according to the recommendations by Hunt and Wilson (1986) and APHA (1995). The samples were properly labeled and kept at $-20{ }^{\circ} \mathrm{C}$ before analysis according to Uddin et al. (2007).

\section{Water sample processing}

Five hundred milliliter of water sample and $100 \mathrm{ml}$ solvent ( $2 \%$ diethyl ether in double-distilled $n$-hexane) were taken into a 1,000-ml capacity separating funnel (DURAN, Germany) and was shaken by mixing well for about $10 \mathrm{~min}$ and then kept standing for 10-15 min for settling down. The organic solvent was collected in a conical flask. The aqueous layer was re-extracted by adding $50 \mathrm{ml}$ of solvent mixture using a similar procedure. The organic solvent layers were aspirated and combined before the addition of $20 \mathrm{~g}$ of anhydrous sodium sulfate (Merck, Germany) to remove the residual water. The collected extract was then concentrated to a smaller volume of $5 \mathrm{ml}$ under reduced pressure using a rotary vacuum evaporator (Rotavapor-R 215, Buchi, Switzerland) based on the method described in the Deutsche Forschungsgemeinschaft (Thier and Zeumer 1987). The samples were cleaned up by following the method described by (Bhattacharjee et al. 2012). In brief, the concentrated samples were passed through a column (10 mm ID) packed with $10 \mathrm{~g}$ of deactivated florisil (Sigma, USA) and synthetic magnesium silicate (60-100 mesh). The florisil was activated at $200{ }^{\circ} \mathrm{C}$ for $6 \mathrm{~h}$ and was subsequently deactivated with $2 \%$ distilled water. The top $1.5 \mathrm{~cm}$ of the florisil column was packed with anhydrous sodium sulfate. Elution was performed with a solvent mixture of double-distilled hexane (90\%) and dichloromethane $(10 \%)$ at $5 \mathrm{ml} / \mathrm{min}$. The eluent was further concentrated in a rotary vacuum evaporator (Buchi, Switzerland) before being transferred to a glass vial. Solvents were completely removed under a gentle flow of fresh nitrogen from a Nitrogen blower (PU 90003, ALFA industry, England). The evaporated sample was dissolved in acetonitrile, and a 1-ml volume was used for the HPLC analysis.

\section{Pesticide analysis by HPLC}

After the sample cleanup, aliquots of the final volume were quantified with a HPLC system (SHIMADZU LC10 Avp-Series Automated with LC Solution Software LabSolutions (LC solution Release 1.11SP1) that was equipped with a SPD-M 10 Avp outfitted with a photodiode array (PDA) detector. $\mathrm{A}_{18}$ Reverse Phase Alltech analytical column (5 $\mu \mathrm{m}, 25094.6 \mathrm{~mm})$ was used and 
maintained at $30{ }^{\circ} \mathrm{C}$ in a column oven. The mobile phase, which was a combination of $70 \%$ acetonitrile and $30 \%$ water, was filtered using a cellulose filter $(0.45 \mu \mathrm{m})$ prior to use and was allowed to run at $1.2 \mathrm{ml} / \mathrm{min}$. Prior to the HPLC analysis, the samples were passed through $0.45 \mu \mathrm{m}$ nylon (Alltech Assoc) syringe filters and were manually injected $(20 \mu \mathrm{l})$ into the HPLC system each time. The identification of the suspected pesticide was performed by comparing peak retention times in samples to those of peaks in the pure analytical standard. Quantification was performed using the method described by (Chowdhury et al. 2012a).

The percentage recoveries were calculated using the following equation

Percentage of recovery $=\left[C_{\mathrm{E}} / C_{\mathrm{M}} \times 100\right]$, where $C_{\mathrm{E}}$ is the experimental concentration determined from the calibration curve and $C_{\mathrm{M}}$ is the spiked concentration.

Table 1 Percentage recoveries of tested pesticides for water samples

\begin{tabular}{|c|c|c|c|c|}
\hline \multirow[t]{2}{*}{ Compound } & \multirow[t]{2}{*}{ Cleanup system } & \multicolumn{2}{|c|}{ Concentration $(\mu \mathrm{g} / \mathrm{l})^{\mathrm{a}}$} & \multirow[t]{2}{*}{ Recovery \% } \\
\hline & & Spiked & Measured & \\
\hline \multirow[t]{2}{*}{ Methoxychlor } & Control $^{\mathrm{b}}$ & 0.00 & 0.00 & 0.00 \\
\hline & Florisil cleanup & 400.00 & 357.20 & 89.30 \\
\hline \multirow[t]{2}{*}{ DDT } & Control & 0.00 & 0.00 & 0.00 \\
\hline & Florisil cleanup & 400.00 & 365.80 & 91.45 \\
\hline \multirow[t]{2}{*}{ Chlorpyrifos } & Control & 0.00 & 0.00 & 0.00 \\
\hline & Florisil cleanup & 400.00 & 378.16 & 94.54 \\
\hline \multirow[t]{2}{*}{ Diazinon } & Control & 0.00 & 0.00 & 0.00 \\
\hline & Florisil cleanup & 400.00 & 353.28 & 88.32 \\
\hline \multirow[t]{2}{*}{ Ethion } & Control & 0.00 & 0.00 & 0.00 \\
\hline & Florisil cleanup & 400.00 & 372.48 & 93.12 \\
\hline \multirow[t]{2}{*}{ Fenthion } & Control & 0.00 & 0.00 & 0.00 \\
\hline & Florisil cleanup & 400.00 & 343.92 & 85.98 \\
\hline \multirow[t]{2}{*}{ Fenitrothion } & Control & 0.00 & 0.00 & 0.00 \\
\hline & Florisil cleanup & 400.00 & 357.00 & 89.25 \\
\hline \multirow[t]{2}{*}{ Malathion } & Control & 0.00 & 0.00 & 0.00 \\
\hline & Florisil cleanup & 400.00 & 366.48 & 91.62 \\
\hline \multirow[t]{2}{*}{ Parathion } & Control & 0.00 & 0.00 & 0.00 \\
\hline & Florisil cleanup & 400.00 & 361.64 & 90.41 \\
\hline \multirow[t]{2}{*}{ Carbaryl } & Control & 0.00 & 0.00 & 0.00 \\
\hline & Florisil cleanup & 400.00 & 370.04 & 92.51 \\
\hline \multirow[t]{2}{*}{ Carbofuran } & Control & 0.00 & 0.00 & 0.00 \\
\hline & Florisil cleanup & 400.00 & 373.64 & 93.41 \\
\hline \multirow[t]{2}{*}{ Cypermethrin } & Control & 0.00 & 0.00 & 0.00 \\
\hline & Florisil cleanup & 400.00 & 349.28 & 87.32 \\
\hline
\end{tabular}

\footnotetext{
${ }^{a}$ Mean value of triplicates

b Control is blank sample without spiking of any concentration of pesticides
}

The mean percentage recoveries of all tested pesticides were more than $85 \%$ which was satisfactory. These values were quite satisfactory and meet the requirements of the (European Commission 2000) (Tables 1), indicating that a method can be considered accurate and precise when the accuracy of data is between 70 and $110 \%$. The Limit of detection (LOD) for the pesticides was $0.1 \mu \mathrm{g} / \mathrm{l}$.

Bacteria used in this study

Three bacterial isolates viz., Pseudomonas peli BG1, Burkholderia caryophylli BG4 and Brevundimonas diminuta PD6 were collected from Microbiology and Industrial Irradiation Division, Institute of Food and Radiation Biology (IFRB), Atomic energy Research Establishment, Savar, Dhaka. The organisms were isolated from botanical garden of Jahangirnagar University campus in October 2011 and identified by Mahiuddin (2012).

Growth medium and biodegradation studies

The mineral salt medium used in biodegradation studies, adapted from Cycon et al. (2009), contained (g/l) $\left(\mathrm{NH}_{4}\right)_{2} \mathrm{SO}_{4}, 2.0 ; \mathrm{KH}_{2} \mathrm{PO}_{4}, 1.5 ; \mathrm{Na}_{2} \mathrm{HPO}_{4}, 1.5 ; \mathrm{MgSO}_{4}$ $7 \mathrm{H}_{2} \mathrm{O}, 0.2 ; \mathrm{CaCl}_{2} \cdot 2 \mathrm{H}_{2} \mathrm{O}, 0.01 ; \mathrm{FeSO}_{4} \cdot 7 \mathrm{H}_{2} \mathrm{O}, 0.001$. The $\mathrm{pH}$ of the medium was adjusted to $7.0 \pm 0.1$ with $2 \mathrm{M}$ $\mathrm{NaOH}$. Growth experiments with chlorpyrifos as a sole carbon source were performed in 250-ml conical flasks containing $95 \mathrm{ml}$ of sterile mineral salt medium (MSM). Chlorpyrifos was introduced into MSM prior to inoculation in a form of acetone solution to give the final concentration of 20 and $50 \mathrm{mg} / \mathrm{l}$. After a day of shaking to evaporate the solvent, $5 \mathrm{ml}$ of bacterial suspension $\left(\approx 10^{7}\right)$ was used to inoculate in $95 \mathrm{ml}$ sterile mineral salt medium. Mineral salt medium was sterilized by autoclaving prior to the addition of chlorpyrifos. Triplicate samples for MSM + chlorpyrifos, non-inoculated with the bacterial suspension were kept as controls. After inoculation, flasks were incubated at $30{ }^{\circ} \mathrm{C}$ on a rotary shaker $(120 \mathrm{rpm})$ and kept from the light to avoid photodegradation of chlorpyrifos.

Samples of liquid medium were periodically removed aseptically for measuring of bacterial growth $\left(\mathrm{OD}_{600 \mathrm{~nm}}\right)$ and $\mathrm{pH}$ using UV-visible spectrophotometer (UV-1601, SHIMADZU) and $\mathrm{pH}$ meter (3510 $\mathrm{pH}$ meter, JENWAY, Bibby Scientific Ltd., UK), respectively. A portion ( $\sim 5 \mathrm{ml}$ ) of liquid medium from conical flasks was taken aseptically in centrifuge tube and cells were removed by centrifugation at $8,000 \mathrm{rpm}$ for $10 \mathrm{~min}$. After that the supernatant was taken and allowed to centrifuge again at the same condition. The final supernatant $(\sim 1 \mathrm{ml})$ was taken into eppendorf and kept in refrigerator prior to their analysis using HPLC. The study period for the biodegradation of chlorpyrifos was up to 12 days when $20 \mathrm{mg} / \mathrm{l}$ 
chlorpyrifos was supplied as a sole source of carbon and up to 16 days when $50 \mathrm{mg} / \mathrm{l}$ chlorpyrifos was supplied as a sole source of carbon.

\section{Determination of degradation rate}

The degradation rate by the bacterial isolate under specific conditions was calculated as the following equation: Degradation rate $=\Delta[$ Chlorpyrifos $] / \Delta[\mathrm{t}]$,

where, $\Delta$ [Chlorpyrifos] was the difference of chlorpyrifos concentrations between two sampling times $(\mathrm{mg} / \mathrm{l})$ and $\Delta[t]$ was time difference in days.

\section{Results and discussion}

Level of organochlorines, organophosphorus, carbamates and pyrithrium pesticide residues in agricultural water samples

Twelve water samples from Savar Upazila of Dhaka, Bangladesh were analyzed for some selected organochlorines (OCs), organophosphorus (OPs), carbamates and pyrithrium pesticides using high-performance liquid chromatography (HPLC) with PDA detector. Table 2 presents the results of pesticide residues $(\mu \mathrm{g} / \mathrm{l})$ in water samples. Among organophosphorus pesticides, chlorpyrifos was detected in four samples and concentrations ranged from 3.27 to $9.31 \mu \mathrm{g} / \mathrm{l}$, which was lower than the standard value of Japan (MPHW 1997) whereas diazinon was detected in only one sample at the concentration of $7.86 \mu \mathrm{g} / \mathrm{l}$, which was much higher than the Australian Health Value of $3 \mu \mathrm{g} /$ 1 for diazinon (NHMRC 1996). On the other hand, fenitrothion was detected and concentrations ranged from 5.83 to $33.41 \mu \mathrm{g} / \mathrm{l}$, which was below than the Australian Health Value of $10 \mu \mathrm{g} / \mathrm{l}$ (NHMRC 1996). Parathion was found and concentration ranged from 0.73 to $6.23 \mu \mathrm{g} / \mathrm{l}$, below the Australian Health Value of $10 \mu \mathrm{g} / \mathrm{l}$ (NHMRC 1996) whereas malathion was detected and concentrations ranged from 23.1 to $59.9 \mu \mathrm{g} / \mathrm{l}$, within the Australian Health Value (NHMRC 1996). In this study, ethion was not detected in any of the tested samples whereas fenthion was detected in two samples at the concentration of 25.11 and $56.3 \mu \mathrm{g} / \mathrm{l}$, respectively. Previously investigated diazinon concentrations ranged from no detected to $0.102 \mu \mathrm{g} / \mathrm{l}$ in Axios Greek River (Papadopoulou-Mourkidou 2002), fenitrothion $<1 \mu \mathrm{g} / \mathrm{l}$ (Sudo et al. 2002), parathion methyl from no detected to $271 \mathrm{ng} / \mathrm{l}$ and parathion ethyl from no detected to $40 \mathrm{ng} / \mathrm{l}$ in Kalamas Greek River (Albanis et al. 2004), fenthion residues ranged from 2.2 to $15 \mu \mathrm{g} / \mathrm{l}$ in Kenya (Keith et al. 1994) and 10-30 ng/l in Kalamas River (Lambropoulou et al. 2002). The persistent nature of organophosphorus pesticides and their translocation from agricultural land as runoff or as irrigation return flow can cause residues in water sources.

Among carbamate pesticides, carbaryl was determined and concentrations ranged from 4.6 to $6.3 \mu \mathrm{g} / \mathrm{l}$, whereas carbofuran was detected at a concentration of $43.2 \mu \mathrm{g} / \mathrm{l}$. The values of carbaryl were almost similar to the Australian Guideline Value of $5 \mu \mathrm{g} / \mathrm{l}$ whereas carbofuran was well above the Australian Guideline Value of $5 \mu \mathrm{g} / \mathrm{l}$ (NHMRC (National Health and Medical Research Council) 1996). Carbaryl was detected in Evros basin from 0.046 to $0.077 \mu \mathrm{g} / \mathrm{l}$ (Vryzas et al. 2009). Previously recorded carbofuran ranged from no detected to $160 \mathrm{ng} / \mathrm{l}$ in Kalamas River and no detected to $553 \mathrm{ng} / \mathrm{l}$ in Arachthos River in Greece (Albanis et al. 2004), and 30-150 ng/l from Kalamas River (Lambropoulou et al. 2002).

In this study, cypermethrin was detected in three of the tested samples and concentrations ranged from 54.36 to $80.5 \mu \mathrm{g} / \mathrm{l}$, which are very higher than the Swedish guideline value of $0.0002 \mu \mathrm{g} / \mathrm{l}$ for cypermethrin and EU regulatory value of $0.0068 \mu \mathrm{g} / \mathrm{l}$ for cypermethrin in stagnant water systems (Wijngaarden et al. 2005). Cypermethrin as a hydrophobic organic compound which adsorbs to sediments and according to the literature it is toxic to aquatic organisms (Tomlin 2010). On the other hand, once they have been adsorbed to sediment, they can leach and cause long-term contamination of watercourses (Turgut et al. 2010). Major reported sources of cypermethrin in surface water include agricultural and urban runoff from rainstorms, spray drift, urban landscape irrigation and release of agricultural tailwaters (Wang et al. 2009).

The results of the present study showed that none of the water samples was contaminated with organochlorine (methoxychlor and DDT) pesticides. These may be the ban of organochlorines from the pesticide markets from 1993 according to the Bangladesh Environment Conservation Act 1995 due to their high toxicity (Matin et al. 1998). Another study conducted on the presence of organochlorine residues in water samples from irrigation canals in the Meghna-Dhanogoda irrigation project, Bangladesh, reported that the maximum amount of DDT was $5.7 \mu \mathrm{g} / \mathrm{l}$ (Alam et al. 1999), but in the present study, no DDT was detected in water. Matin et al. (1998) also reported that DDT was present in water from irrigated crop field $1.5 \mu \mathrm{g} / \mathrm{l}$ in Gaibanda and $19.6 \mu \mathrm{g} / \mathrm{l}$ in Begumganj. Golfinopoulos et al. (2003) reported that methoxychlor remains below detection limit in water samples from various lakes at different sampling periods.

The frequent high concentrations (over guideline values) of pesticides detected in the current study are probably due to the extensive utilization of pesticides in the agricultural fields. There are three major sources for surface water contamination by pesticides: inappropriate handling of pesticides (e.g., washing equipment in the river), 


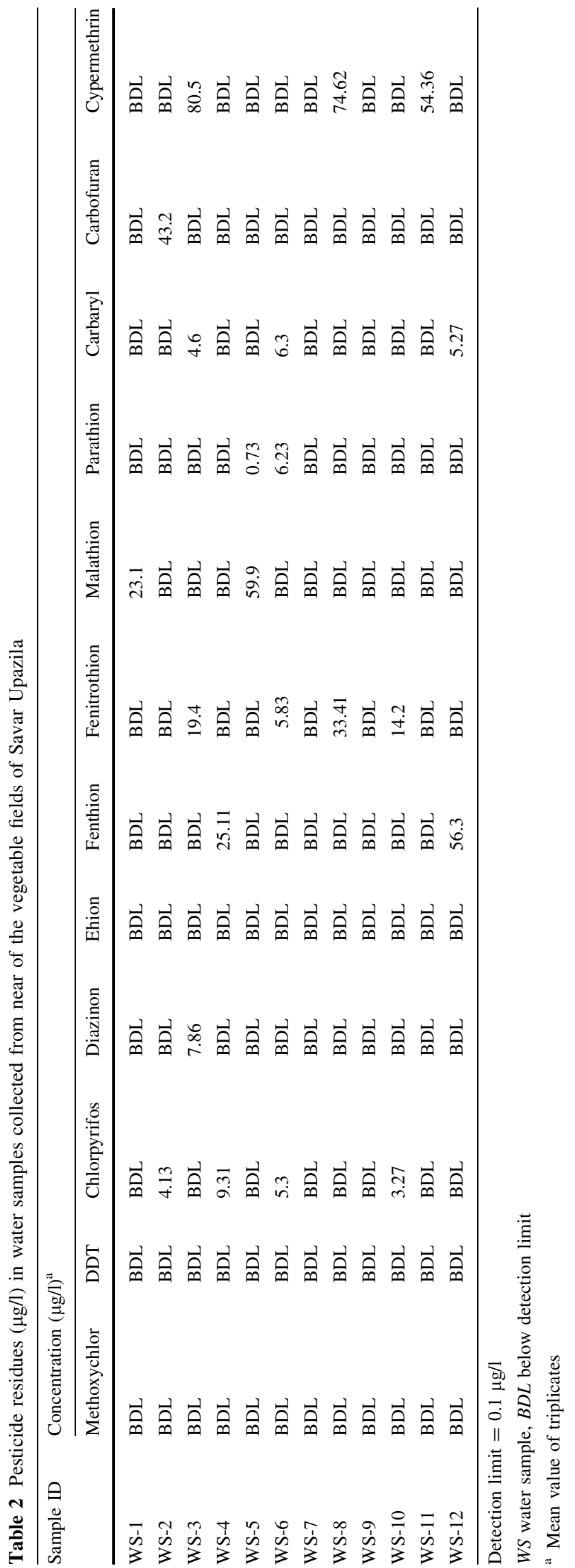

volatilization to air, and residuals from soil and water. In this perspective, the drainage of water from agricultural fields into irrigation channels poses a critical source of risk for contamination by pesticides in the broader water environment (Phong et al. 2010). Rain runoff from agricultural fields that occurred immediately after the application period of pesticides has been pointed to be the major source of pesticides in water bodies (Kreuger 1998). Rainfall, and hence the associated increased runoff, would be expected to result in increased movement of pesticides into nearby water bodies. However, the persistent nature of the pesticides is of great concern due to their bioaccumulative nature and toxic biological effects on wildlife and humans (Tanabe et al. 2000).

Biodegradation of chlorpyrifos by three bacterial strains

Earlier attempts to degrade chlorpyrifos by soil bacterial isolates have not been successful before 2000 (Racke et al. 1994; Mallick et al. 1999). In the present study, biodegradation of chlorpyrifos by three soil bacterial isolates was performed in comparison with bacterial cell growth in the MSM. Growth of bacterial isolates, chlorpyrifos degradation and change in $\mathrm{pH}$ by $P$. peli BG1 when $20 \mathrm{mg} / \mathrm{l}$ chlorpyrifos and $50 \mathrm{mg} / \mathrm{l}$ chlorpyrifos were supplied as sole source carbon, are presented in Fig. 1. The growth of $P$. peli $\mathrm{BG} 1$ reached a maximum $\mathrm{OD}_{600}$ at 6 and 8 days of incubation in $20 \mathrm{mg} / \mathrm{l}$ chlorpyrifos and $50 \mathrm{mg} / \mathrm{l}$ chlorpyrifos, respectively. The results showed that $P$. peli BG1 degrades chlorpyrifos completely within 8 and 14 days of incubation when 20 and $50 \mathrm{mg} / \mathrm{l}$ chlorpyrifos were supplied as sole source of carbon, respectively. But the bacterial growth and chlorpyrifos degradation were both increased rapidly during 2 days of incubation in chlorpyrifos-containing medium. Result also represented that, when growth of the bacterial cell increased, chlorpyrifos degradation also relatively increased, similar results also found in other studies (Xu et al. 2007, 2008). Xu et al. (2007) observed the complete disappearance of $50 \mathrm{mg} / \mathrm{l}$ chlorpyrifos due to Serratia sp. TCR cultivated in mineral salt medium within 4 days. Similar results were recorded by Zhu et al. (2010) and $100 \mathrm{mg} / \mathrm{l}$ of chlorpyrifos was completely degraded by $B$. licheniformis ZHU-1 within 14 days. At 25 and $50 \mathrm{mg} / \mathrm{l}$ chlorpyrifos, maximum microbial growth was attained on the 5th day and thereafter growth declined during degradation of chlorpyrifos by Pseudomonas aeruginosa (Huang et al. 2000). Li et al. (2008) reported that approximately $98 \%$ of chlorpyrifos was degraded within 10 days by seven bacterial isolates belonging to Pseudomonas genus collected from soil.

Figure 2 presents the both bacterial growth and degradation of chlorpyrifos for the isolate $B$. caryophylli $\mathrm{BG} 4$ when 20 and $50 \mathrm{mg} / \mathrm{l}$ chlorpyrifos were used, respectively, 

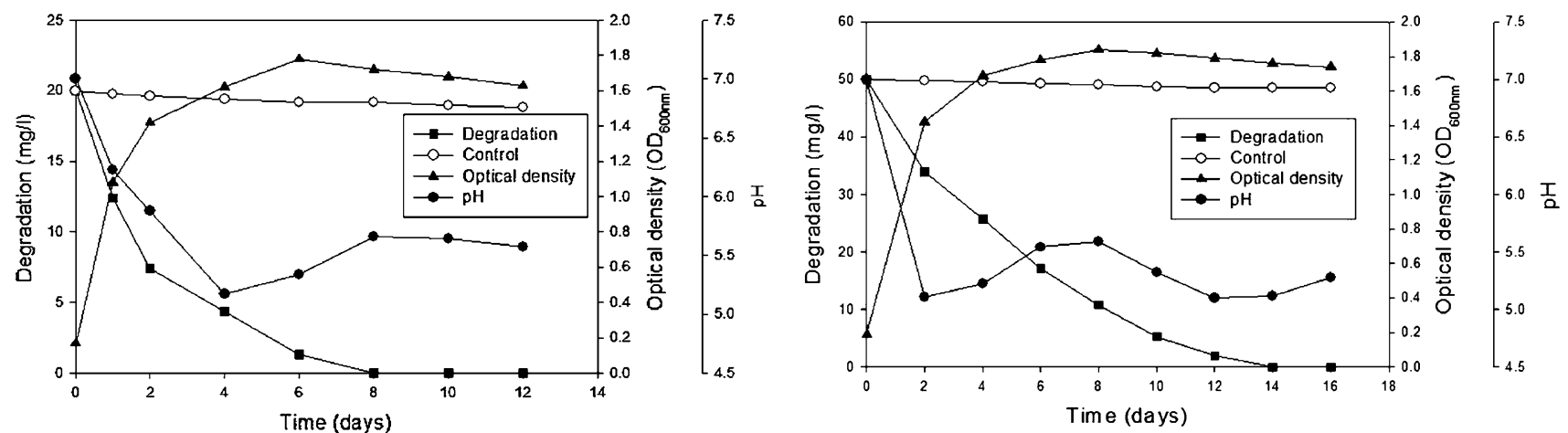

Fig. 1 Chlorpyrifos degradation, growth and change in $\mathrm{pH}$ by Pseudomonas peli BG1 when 20 and $50 \mathrm{mg} / \mathrm{l}$ chlorpyrifos were supplied as sole source of carbon
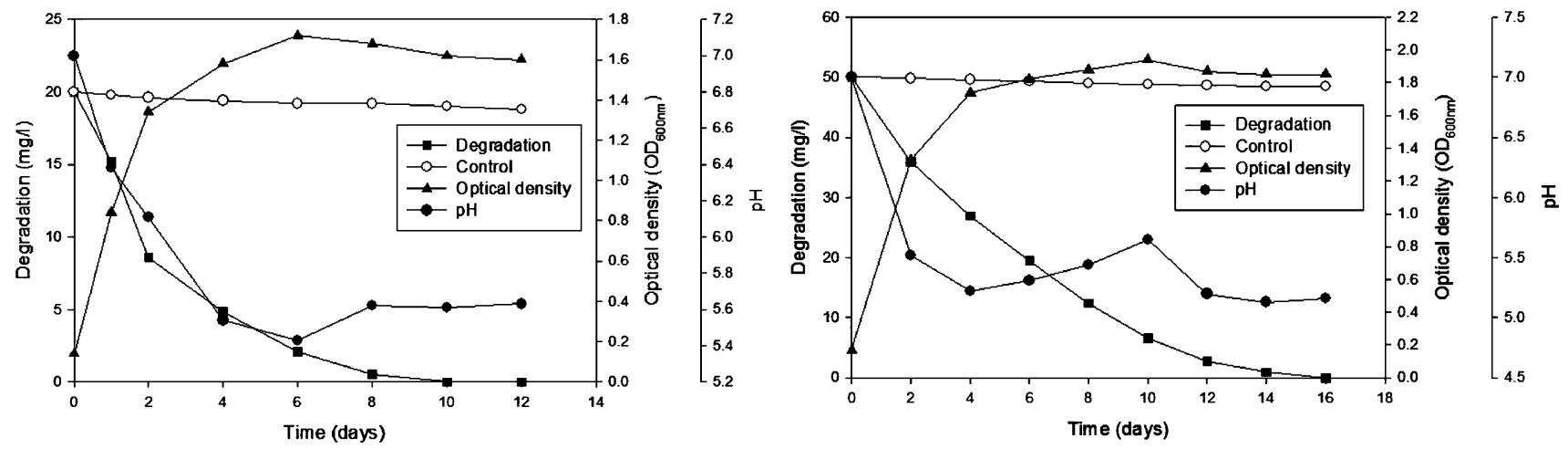

Fig. 2 Chlorpyrifos degradation, growth and change in pH by Burkholderia caryophylli BG4 when 20 and 50 mg/l chlorpyrifos were supplied as sole source of carbon
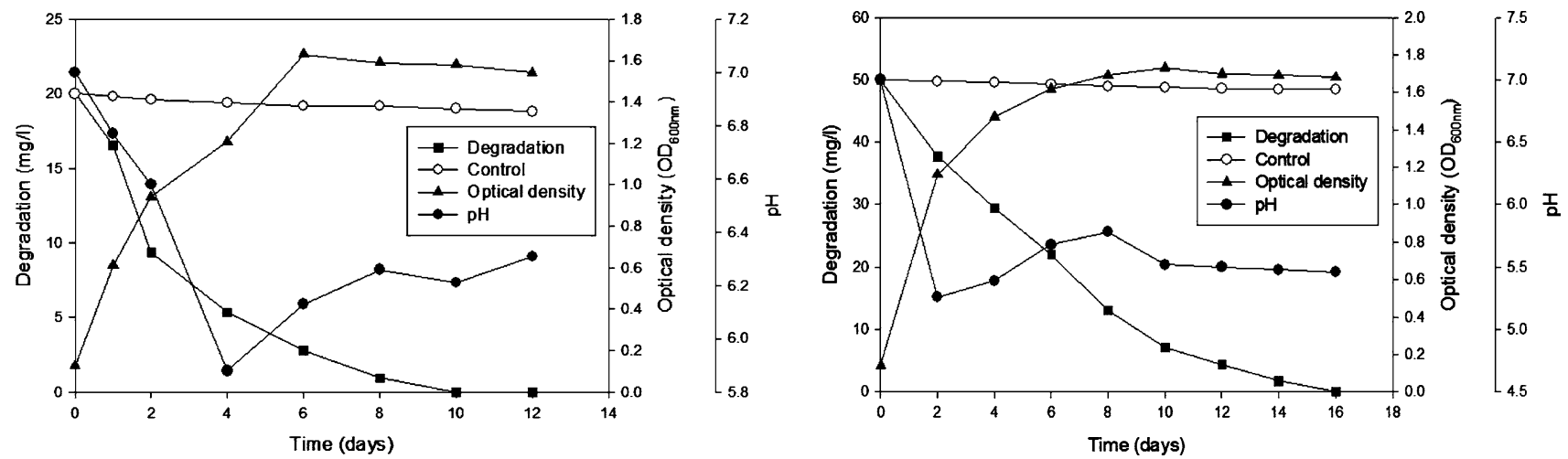

Fig. 3 Chlorpyrifos degradation, growth and change in pH by Brevundimonas diminuta PD6 when 20 and 50 mg/l chlorpyrifos were supplied as sole source of carbon

as sole carbon source, respectively. The cell growth reached a maximum after $6(20 \mathrm{mg} / \mathrm{l})$ days and $10(50 \mathrm{mg} /$ 1) days of incubation and chlorpyrifos was completely degraded within 10 and 16 days of incubation in 20 and $50 \mathrm{mg} / \mathrm{l}$ chlorpyrifos-containing medium, respectively. The $\mathrm{pH}$ range was 7-5.43 during degradation of chlorpyrifos at the concentration of $20 \mathrm{mg} / \mathrm{l}$ and 7-5.13 when concentration was $50 \mathrm{mg} / \mathrm{l}$. The results revealed that $\mathrm{pH}$ drastically decline in 2 days of incubation and maximum degradation was found in $50 \mathrm{mg} / \mathrm{l}$ of chlorpyrifos. The isolated Enterobacter species were capable of degrading chlorpyrifos in the $\mathrm{pH}$ range from 5.5 to 7.6 (Singh et al. 2004). Kim and Ahn (2009) were examined the degradation of different insecticides in MSM cultures using Burkholderia sp. strain KR100 cell extract.

For the isolate B. diminuta PD6, the results of bacterial growth and degradation of chlorpyrifos are presented in Fig. 3 when 20 and $50 \mathrm{mg} / \mathrm{l}$ chlorpyrifos were supplied as 
sole source of carbon, respectively. The results showed that growth of bacterial cell was reached a maximum after 6 $(20 \mathrm{mg} / \mathrm{l})$ days and $10(50 \mathrm{mg} / \mathrm{l})$ days of incubation and chlorpyrifos was completely degraded within 10 and 16 days of incubation in $20 \mathrm{mg} / \mathrm{l}$ chlorpyrifos and $50 \mathrm{mg} / \mathrm{l}$ chlorpyrifos-containing medium, respectively. The growth of the isolate $B$. diminuta PD6 was not increased after complete degradation of chlorpyrifos. The $\mathrm{pH}$ range was 7-5.88 during degradation of chlorpyrifos by $B$. diminuta at the concentration of $20 \mathrm{mg} / \mathrm{l}$ and 7-5.26 when concentration was $50 \mathrm{mg} / \mathrm{l}$. The results also revealed that $\mathrm{pH}$ rapidly decline in 2 days of incubation and maximum degradation was found in $50 \mathrm{mg} / \mathrm{l}$ of chlorpyrifos. Maximum chlorpyrifos degradation rate by $B$. diminuta PD6 was found during 2 days of incubation in both $20 \mathrm{mg} / \mathrm{l}$ chlorpyrifos and $50 \mathrm{mg} / \mathrm{l}$ chlorpyrifos-containing medium. Previously Desdpande (2002) isolated two strains belonged to the genus Brevundimonas and identified as Brevundimonas sp. to study the effect of various environmental factors on growth and dimethoate (an organophosphorus insecticide) degradation; the isolate Brevundimonas sp. was grown in Davis Mingiolo's synthetic medium containing $500 \mathrm{mg} / \mathrm{l}$ of dimethoate as sole source of carbon and energy.

Though a little information exists regarding the ability to degrade chlorpyrifos by bacteria belonging to Burkholderia and Brevundimonas species, some studies showed a lot of information about the efficient degradation of chlorpyrifos performed by the different species of Pseudomonas (Digrak et al. 1995; Huang et al. 2000; Li et al. 2008; Rani et al. 2008; Xu et al. 2008; Liu et al. 2012). Chlorpyrifos has also been reported to be degraded cometabolically by bacteria, which needs extra carbon sources (Richins et al. 1997; Mallick et al. 1999). Singh et al. (2004) reported isolation of Enterobacter sp. B14, which can use chlorpyrifos for the supply of carbon and phosphorous sources, which it stopped degrading chlorpyrifos in the presence of other carbon sources. Recently, Enterobacter strain B-14 (Singh et al. 2003), Alcaligenes faecalis DSP3 (Yang et al. 2005) and Stenotrophomonas sp. (Yang et al. 2006; Lakshmi et al. 2008) were isolated and showed an enhanced degradation of chlorpyrifos.

\section{Chlorpyrifos biodegradation rate}

The degradation rate patterns of chlorpyrifos in MSM supplemented with 20 and $50 \mathrm{mg} / \mathrm{l}$ chlorpyrifos are presented in Fig. 4. It was observed that the chlorpyrifos degradation rate for these three isolates was different at the same incubation period when grown in MSM supplemented with 20 and $50 \mathrm{mg} / \mathrm{l}$ chlorpyrifos. Maximum chlorpyrifos degradation rates by all three isolates were found in 2nd day of incubation for both 20 and $50 \mathrm{mg} / \mathrm{l}$ chlorpyrifos. From the results it was also found that the degradation rate was relatively higher for all isolates during first 6 days of incubation but then it decreased sharply. During the first 2 days of incubation period, chlorpyrifos was degraded at a maximum rate of $6.3,5.7$ and $5.3 \mathrm{mg} / \mathrm{l} /$ day for isolates BG1, BG4 and PD6, respectively, when MSM supplemented with $20 \mathrm{mg} / \mathrm{l}$ chlorpyrifos. On the other hand, the maximum degradation rates were obtained by the isolates BG1, BG4 and PD6 with 8.04, 7.04 and 6.14 $\mathrm{mg} / \mathrm{l} / \mathrm{d}$, respectively, after 2 days of incubation when MSM supplemented with $50 \mathrm{mg} / \mathrm{l}$ chlorpyrifos.

In this study, it has been found that the chlorpyrifos degradation rates by the isolates $P$. peli $\mathrm{BG} 1, B$. caryophylli BG4 and $B$. diminuta PD6 were greatly increased due to increase in the concentration of chlorpyrifos; similar results were found in other studies ( $\mathrm{Li}$ et al. 2008; Xu et al. 2008). Li et al. (2008) also showed that $100 \mathrm{mg} / \mathrm{l}$ chlorpyrifos was degraded to an undetectable level in $24 \mathrm{~h}$ by
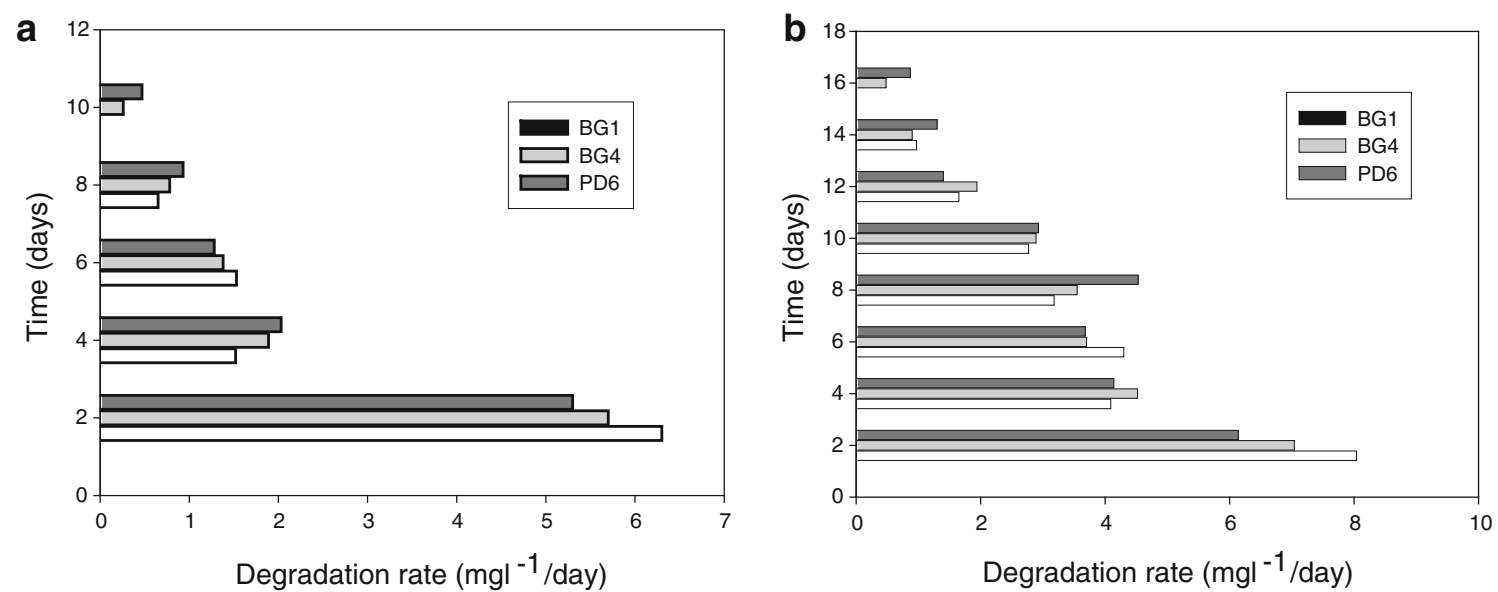

Fig. 4 Degradation rate of chlorpyrifos by the three isolates Pseudomonas peli BG1, Burkholderia caryophylli BG4 and Brevundimonas diminuta PD6 when grown in MSM containing a $20 \mathrm{mg} / \mathrm{l}$ and b $50 \mathrm{mg} / \mathrm{l}$ concentration of chlorpyrifos 
strain Dsp-2 belonging Pseudomonas genus. Contrast of the results also demonstrated by Liu et al. (2012) that the degradation rate was decreased slowly with the concentration of chlorpyrifos being increased from 100 to $150 \mathrm{mg} / \mathrm{l}$. The degradation of chlorpyrifos by $P$. fluorescence, B. melitensis and B. subtilis was 43,45 and $56 \%$, respectively, after 10 days of incubation and 89, 87 and $85 \%$, respectively, after 30 days of incubation, when $50 \mathrm{mg} / \mathrm{l}$ chlorpyrifos was supplied as sole source of carbon (Lakshmi et al. 2008).

\section{Conclusions}

Surface waters adjacent to agricultural area of Savar Upazila were contaminated with pesticide residues, particularly chlorpyrifos, fenitrothion, fenthion, malathion, carbaryl and cypermethrin. Other pesticides detected were parathion, diazinon and carbofuran. In the tested samples, chlorpyrifos, fenitrothion and parathion were found ranged from 3.27 to $9.31 \mu \mathrm{g} / \mathrm{l}, 5.83$ to $33.41 \mu \mathrm{g} / \mathrm{l}$, and 0.73 to $6.23 \mu \mathrm{g} / 1$, respectively. Carbaryl, cypermethrin and malathion were recorded ranged from 4.6 to $6.3 \mu \mathrm{g} / \mathrm{l}, 54.36$ to $80.5 \mu \mathrm{g} / \mathrm{l}$ and 23.1 to $59.9 \mu \mathrm{g} / \mathrm{l}$, respectively. None of the water sample was found to be contaminated with Methoxychlor, DDT and Ethion. Proper utilization and routine monitoring programs for these pesticide residues in agro-environment are needed to prevent, control and reduce the pollution.

Pseudomonas peli BG1, B. caryophylli BG4 and B. diminuta PD6 degraded chlorpyrifos completely in 8, 10 and 10 days of incubation, respectively, when $20 \mathrm{mg} / \mathrm{l}$ chlorpyrifos was supplied as sole source of carbon. On the other hand, BG1, BG4 and PD6 took 14, 16 and 16 days, respectively, when the concentration of chlorpyrifos was $50 \mathrm{mg} / \mathrm{l}$. Maximum chlorpyrifos degradation rates were recorded by all three bacterial isolates at 2 nd day of incubation for both tested concentrations of 20 and $50 \mathrm{mg} /$ 1. Isolates BG1, BG4 and PD6 can be used successfully for the bioremediation of chlorpyrifos-contaminated sites.

Open Access This article is distributed under the terms of the Creative Commons Attribution License which permits any use, distribution, and reproduction in any medium, provided the original author(s) and the source are credited.

\section{References}

Alam MN, Das NG, Rahman MM, Malek MA (1999) Organochlorine insecticide residues in water and soil of the Meghna Dhonagoda irrigation project of Bangladesh. J Asiat Soc Bangladesh Sci 25:135-142

Albanis TA, Hela DG, Lambropoulou DA, Sakkas VA (2004) Gas chromatographic mass spectrometric methodology using solid phase microextraction for the multiresidue determination of pesticides in surface waters (N.W. Greece). Int J Environ Anal Chem 84:1079-1092

Anwar S, Liaquat F, Khan QM, Khalid ZM, Iqbal S (2009) Biodegradation of chlorpyrifos and its hydrolysis product 3,5,6-trichloro-2-pyridinol by Bacillus pumilus strain C2A1. J Hazard Mater 168:400-405

APHA (1995) Standard methods for the examination of water and waste water, 19th edn. American Water Works Association and Water Environement Federation, American Public Health Association. Washington, DC, pp 1-30 and 40-175

Bhattacharjee S, Fakhruddin ANM, Chowdhury MAZ, Rahman MA, Alam MK (2012) Monitoring of selected pesticides residues levels in water samples of paddy fields and removal of cypermethrin and chlorpyrifos residues from water using rice bran. Bull Environ Contam Toxicol 89:348-353

Briceño G, Fuentes MS, Palma G, Jorquera MA, Amoroso MJ, Diez MC (2012) Chlorpyrifos biodegradation and 3,5,6-trichloro-2pyridinol production by actinobacteria isolated from soil. Int Biodeterior Biodegrad 73:1-7

Cerejeira MJ, Viana P, Batista S, Pereira T, Silva E, Valerio MJ, Silva A, Ferreira M, Silva-Fernandes AM (2003) Pesticides in Portuguese surface and ground waters. Water Res 37:1055-1063

Cho CM, Mulchandani A, Chen W (2002) Bacterial cell surface display of organophosphorus hydrolase for selective screening of improved hydrolysis of organophosphate nerve agent. Appl Environ Microbiol 68:2026-2030

Chowdhury MTI, Razzaque MA, Khan MSI (2011) Chlorinated pesticides residue status in tomato, potato and carrot. J Exp Sci 2(1): $1-5$

Chowdhury MAZ, Jahan SA, Islam MN, Moniruzzaman M, Alam MK, Zaman MA, Karim N, Gan SH (2012a) Occurrence of organophosphorus and carbamate pesticide residues in surface water samples from the Rangpur district of Bangladesh. Bull Environ Contam Toxicol 89:202-207

Chowdhury MAZ, Banik S, Uddin B, Moniruzzaman M, Karim N, Gan SH (2012b) Organophosphorus and carbamate pesticide residues detected in water samples collected from paddy and vegetable fields of the Savar and Dhamrai upazilas in Bangladesh. Int J Environ Res Public Health 9:3318-3329

Cycon M, Wojcik M, Piotrowska-Seget Z (2009) Biodegradation of the organophosphorus insecticide diazinon by Serratia sp. and Pseudomonas sp. and their use in bioremediation of contaminated soil. Chemosphere 76:494-501

Dasgupta S, Meisner C, Huq M (2007) A pinch or a pint? Evidence of pesticide overuse in Bangladesh. J Agric Econ 58:91-114

Desdpande NM (2002) Biodegradation of dimethoate a carbamate group of organophosphorus insecticides. Ph. D. Thesis. Department of Microbiology, University of Pune, India

Digrak M, Ozcelik S, Celik S (1995) Degradation of ethion and methidation by some microorganisms. In: 35th IUPAC Congress, vol 14. Istanbul pp 19-84

EC (European Commission) (2000) Quality control procedures for pesticide residues analysis. Guidelines for residues monitoring in the European Union. SANCO/3103/2000

Golfinopoulos SK, Nikolaou AD, Kostopoulou MN, Xilourgidis NK, Vagi MC, Lekkas DT (2003) Organochlorine pesticides in the surface waters of Northern Greece. Chemosphere 50:507-516

Huang XL, Linda S, Naktsu C (2000) Impact of animal waste lagoon effluents on chlorpyrifos degradation in soils. J Environ Technol Chem 19(12):2864-2870

Huber A, Bach M, Frede HG (2000) Pollution of surface waters with pesticides in Germany: modeling non-point source inputs. Agric Ecosyst Environ 80:191-204

Hunt DTE, Wilson AL (1986) The chemical analysis of water-general principles and techniques, 2nd edn. The Royal Society of Chemistry, Cambridge, pp 29-43 
Keith JO, Ngondi JG, Bruggers RI, Kimball BA, Elliott CCH (1994) Environmental effects on wetlands of Queletox applied to ploceid roosts in Kenya. Environ Toxicol Chem 13:333-341

Kim J-R, Ahn Y-J (2009) Identification and characterization of chlorpyrifos methyl and 3,5,6-trichloro-2-pyridinol degrading Burkholderia sp. strain KR100. Biodegradation 20:487-497

Kreuger J (1998) Pesticides in stream water within an agricultural catchment in southern Sweden, 1990-1996. Sci Total Environ 216:227-251

Lakshmi CV, Kumarb M, Khanna S (2008) Biotransformation of chlorpyrifos and bioremediation of contaminated soil. Int Biodeterior Biodegrad 62:204-209

Lambropoulou DA, Sakkas VA, Hela DG, Albanis TA (2002) Application of solid phase microextraction (SPME) in monitoring of priority pesticides in Kalamas River (N.W. Greece). J Chromatogr A 963:107-116

Leonard RA (1990) Movement of pesticides into surface waters. In: Cheng HH (ed) Pesticides in the soil environment: processes, impacts and modeling. Soil Science Society of America, Madison, pp 303-349

Li X, Jiang J, Gu L, Ali SW, He J, Li S (2008) Diversity of chlorpyrifos-degrading bacteria isolated from chlorpyrifos-contaminated samples. Int Biodeterior Biodegrad 62:331-335

Liu Z, Chen X, Shi Y, Su ZC (2012) Bacterial degradation of chlorpyrifos by Bacillus cereus. Adv Mater Res 356-360:676-680

Mahiuddin M (2012) Biodegradation of organophosphate insecticide diazinon by three soil baceterial isolates. MS thesis. Department of Environmental Sciences. Jahangirnagar University, Savar, Dhaka, Bangladesh

Mallick K, Bharati K, Banerji A, Shakil NA, Sethunathan N (1999) Bacterial degradation of chlorpyrifos in pure culture and in soil. Bull Environ Contam Toxicol 62:48-54

Matin M, Malek M, Amin M, Rahman S, Khatoon J, Rahman M, Aminuddin M, Mian A (1998) Organochlorine insecticide residues in surface and underground water from different regions of Bangladesh. Agric Ecosyst Environ 69:11-15

MPHW (Ministry of Public Health and Welfare) (1997) Various standards for agricultural chemicals concerning water quality. (Information from Norio Kurihara), Japan

NHMRC (National Health and Medical Research Council) (1996) Australian drinking water guidelines. Agricultural and Resource Management Council of Australia and New Zealand. Commonwealth of Australia

Papadopoulou-Mourkidou E (2002) Quality of surface waters of Macedonia- Thrace, Northern Greece, Quality control program, Final Report (in Greek). Ministry of Agriculture, Thessaloniki

Phong T, Yoshino K, Hiramatsu K, Harada M, Inoue T (2010) Pesticide discharge and water management in a paddy catchment in Japan. Paddy Water Environ 8:361-369

Planas C, Caixach J, Santos FJ, Rivera J (1997) Occurrence of pesticides in Spanish surface waters. Analysis by high-resolution gas chromatography coupled to mass spectrometry. Chemosphere 34:2393-2406

Racke KD, Fontaine DD, Yoder RN, Miller JR (1994) Chlorpyriphos degradation in soil at termiticidal application rates. Pestic Sci 42:43-51

Rani MS, Lakshmi KV, Devi PS, Madhuri RJ, Aruna S, Jyothi K, Narasimha G, Venkateswarlu K (2008) Isolation and characterization of a chlorpyrifos degrading bacterium from agricultural soil and its growth response. Afr J Microbiol Res 2:26-31

Richins D, Kaneva I, Mulchandani A, Chen W (1997) Biodegradation of organophosphorus pesticides by surface-expressed organophosphorus hydrolase. Nat Biotechnol 15:984-987
Shahjahan AKM (1993) Practical approaches to crop pest and disease management in Bangladesh, Bangladesh Agricultural Research Council. Bangladesh, Dhaka 168

Singh BK, Walker A, Morgan AJW, Wright DJ (2003) Effects of soil $\mathrm{pH}$ on the biodegradation of chlorpyrifos and isolation of a chlorpyrifos-degrading bacterium. Appl Environ Microbiol 69:5198-5206

Singh BK, Walker A, Morgan JAW, Wright DJ (2004) Biodegradation of chlorpyrifos by Enterobacter strain B-14 and its use in Bioremediation of contaminated soils. Appl Environ Microbiol 70(8):4855-4863

Sudo M, Kunimatsua T, Okubo T (2002) Concentration and loading of pesticide residues in Lake Biwa basin (Japan). Water Res 36:315-329

Tanabe S, Prudente MS, Kan-atireklap S, Subramanian A (2000) Mussel watch: marine pollution monitoring of butyltins and organochlorines in coastal waters of Thailand, Philippines and India. Ocean Coast Manag 43:819-839

Thier HP, Zeumer H (1987) Manual of pesticide residue analysis, vol 1. Pesticide Commission, Weinheim, pp 297-307

Tomlin C (2010) The e-Pesticide Manual, Version 5.1. The British Crop Protection Council, Surrey, UK

Turgut C, Atatanir L, Cutright T (2010) Evaluation of pesticide contamination in Dilek National Park, Turkey. Environ Monit Assess 170:671-679

Uddin MA, Chowdhury MAZ, Rahman MS (2007) Studies on DDT residue and its metabolites in dry fishes from different regions of Bangladesh. Bangladesh J Zool 35:107-114

USGS (U.S. Geological Survey) (1999) The quality of our Nation's waters-Nutrients and pesticides: U.S. Geological Survey Circular 1225. pp 82

Vryzas Z, Vassiliou G, Alexoudis C, Papadopoulou-Mourkidou E (2009) Spatial and temporal distribution of pesticide residues in surface waters in northeastern Greece. Water Res 43:1-10

Wagenet RJ (1987) Processes influencing pesticide loss with water under conservation tillage. In: Logan TJ, Davinson JM, Baker $\mathrm{JL}$, Overcash MR (eds) Effect of conservation tillage on groundwater quality: nitrates and pesticides. Lewis, Chelsea, pp 189-204

Wang D, Weston DP, Lydy MJ (2009) Method development for the analysis of organophosphate and pyrethroid insecticides at low parts per trillion levels in water. Talanta 78:1345-1351

Wijngaarden R, Brock T, Brink P (2005) Threshold levels for effects of insecticides in freshwater ecosystems: a review. Ecotoxicology 14:355-380

Xu G, Li Y, Zheng W, Peng X, Li W, Yan Y (2007) Mineralization of chlorpyrifos by co-culture of Serratia and Trichosporon spp. Biotechnol Lett 29:1469-1473

Xu G, Zheng W, Li Y, Wang S, Zhang J, Yan Y (2008) Biodegradation of chlorpyrifos and 3,5,6-trichloro-2-pyridinol by a newly isolated Paracoccus sp. strain TRP. Int Biodeterior Biodegrad 62:51-56

Yang L, Zhao YH, Zhang BX, Yang CH, Zhang X (2005) Isolation and characterization of a chlorpyrifos and 3, 5, 6- trichloro-2pyridinol degrading bacterium. FEMS Microbiol Lett 251:67-73

Yang C, Liu N, Guo X, Qiao C (2006) Cloning of $m p d$ gene from a chlorpyrifos degrading bacterium and use of this strain in bioremediation of contaminated soil. FEMS Microbiol Lett 265:118-125

Zhu J, Zhao Y, Qiu J (2010) Isolation and application of a chlorpyrifos-degrading Bacillus licheniformis ZHU-1. Afr J Microbiol Res 4(22):2410-2413 